\title{
Writing 3D patterns of microvessels
}

This article was published in the following Dove Press journal:

International Journal of Nanomedicine

12 July 2012

Number of times this article has been viewed

\section{Saulius Juodkazis}

Centre for Micro-Photonics, Swinburne University of Technology and Melbourne Centre for Nanofabrication, Victoria, Australia
Correspondence: Saulius Juodkazis Swinburne University of Technology, Centre for Micro-Photonics (H34), John Street, PO Box 218, Hawthorn, Victoria, 3122 Australia

Tel +6I 392148718

Fax +61392145435

Email sjuodkazis@swin.edu.au
Abstract: The laser polymerization capabilities of biocompatible and cross-linkable materials using direct laser writing are discussed.

Purpose: Cross-disciplinary highlight of synergy between medical applications and laser microfabrication.

Keywords: laser microstructuring of materials, femtosecond laser fabrication, direct write, scaffolds, tissue engineering

A recently published paper $^{1}$ demonstrates how femtosecond direct laser writing is used to create complex and arbitrarily arranged three-dimensional (3D) patterns that serve as cellular scaffolds in a biodegradable polylactic-co-glycolic acid (PLGA) polymer. These scaffolds become microvessels and can be potentially used for grafting. Femtosecond laser writing has resolution from submicrometer to hundredsof-micrometers in different materials; this makes it a very promising technique for such applications. Direct write is particularly efficient when 3D capability without a large volume of modification is required, as well as where parallel methods, such as interference fields, are faster and can be used for large area/volume structuring. In the fields of medical and bio/cellular research, femtosecond direct laser write is expected to find a much wider use. The obvious advantage of femtosecond laser pulses over longer pulsed irradiation is the precision of energy delivery, which occurs on a shorter time scale than then material's reaction time, ie, before it "knows" that it is being modified. This is because the absorbed energy is delivered via electronic excitation, which later relaxes, heats, and modifies the region of exposure long after (few picoseconds and onwards) the light pulse (subpicosecond) is gone. This is a welcomed feature for microsurgery, painless skin penetration, and the high precision fabrication of 3D scaffolds using controlled laser writing. ${ }^{1}$

Focused ultrashort laser pulses can create modifications deep below the surface of transparent material where high light intensity changes material locally by absorption at the volumes of micrometer cross-sections and even smaller. The same principle applies to materials without the additives that are usually used to enhance the absorption of the laser light. Additives, such as photoinitiators in resists and resins, can be toxic, not stable, etc. Rather than preparing very specialized material that is optimized for a specific wavelength of excitation, cross-linking and polymerization can be achieved on a micrometer scale via controlled heating. ${ }^{3}$ This optical curing by scanning a hot microspot allows for the opportunity to directly write 3D structures in 
PLGA, polyethylene glycol, polydimethylsiloxane, etc, and the creation of biodegradable and biocompatible scaffolds for cell cultures and tissue engineering.

3D photonic micropatterns and structures, such as lenses, gratings, and photonic crystals, are routinely created using direct laser writing. This field began by using the strong engineering basis of rapid prototyping and has matured over the last 10-15 years. These days, there are different types of laser fabrication and there is a distinct trend of delivering 3D structuring on different scales and for different materials. This trend began with the principles of stereolithography (1980s), where photocurable resin polymer was exposed to an ultraviolet light source and polymerized at the liquid interface, and eventually implemented 3D printing (from early 2000), where there is a wide range of material choices and the ability to cater to different industries in material engineering that use polymers, as well as granular and powder metals and ceramics, for rapid prototyping. This manufacturing process is based on automation and computer-assisted design. The principles of industrial macroscale applications are now implemented in femtosecond direct laser writing for the fabrication on the scale spanning 0.1-100 micrometers, as well as for the structuring of microoptic and photonic materials. ${ }^{4}$ This is the size range within which optical micro/fiberoptical devices are functional and can control light propagation, collection, and detection. Promising new applications appear in the field where microoptics is used to interface with nerve cells via optogenetic technology. ${ }^{5}$
In addition to the optical functions, the mechanical strength of the scaffolds can be optimized by controlling the volume fraction of the solid polymerized volume and free space. This is a powerful tool that is used to match the mechanical properties of laser-fabricated scaffolds and grafts with real tissue. Obviously, these principles are applicable to biomedical implementations on macroscale, eg, for bone, joint, or dental implants. Recent demonstration of a medical application ${ }^{1}$ concerned with medical applications and nanoscale research is timely and highly motivating for the laser microfabrication community.

\section{Disclosure}

The author reports no conflicts of interest in this work.

\section{References}

1. Wang HW, Cheng CW, Li CW, et al. Fabrication of pillared PLGA microvessel scaffold using femtosecond laser ablation. Int J Nanomedicine. 2012;7:1865-1873.

2. Misawa H, Juodkazis S, editors. 3D Laser Microfabrication: Principles and Applications. Philadelphia, PA: Wiley; 2006.

3. Seet KK, Jarutis V, Juodkazis S, et al. Feature-size reduction of photopolymerized structures by femtosecond optical curing of SU-8. Appl Phys Lett. 2006;89(2):024106/1-3.

4. Malinauskas M, Žukauskas A, Purlys V, et al. Femtosecond laser polymerization of hybrid/integrated micro-optical elements and their characterization. J Opt. 2010;12:124010.

5. Crick F, The impact of molecular biology on neuroscience. Philos Trans R Soc Lond B Biol Sci. 1999;354(1392):2021-2025.
International Journal of Nanomedicine

\section{Publish your work in this journal}

The International Journal of Nanomedicine is an international, peerreviewed journal focusing on the application of nanotechnology in diagnostics, therapeutics, and drug delivery systems throughout the biomedical field. This journal is indexed on PubMed Central, MedLine, CAS, SciSearch ${ }^{\circledR}$, Current Contents ${ }^{\circledR} /$ Clinical Medicine,

\section{Dovepress}

Journal Citation Reports/Science Edition, EMBase, Scopus and the Elsevier Bibliographic databases. The manuscript management system is completely online and includes a very quick and fair peer-review system, which is all easy to use. Visit http://www.dovepress.com/ testimonials.php to read real quotes from published authors. 